\title{
21. STABLE ISOTOPE RELATIONSHIPS IN PELAGIC LIMESTONES FROM THE CENTRAL CARIBBEAN: LEG 15, DEEP SEA DRILLING PROJECT
}

\author{
Thomas F. Anderson and Nahum Schneidermann ${ }^{1}$, Department of Geology, \\ University of Illinois, Urbana, Illinois
}

\section{INTRODUCTION}

Upper Cretaceous (Coniacian to Maestrichtian) pelagic limestones were recovered from the lower parts of several cores from Leg 15 of the Deep Sea Drilling Project. The limestones are characterized by a nanno-mosaic matrix and by the presence of microspar and spar infilling of foraminifera and radiolaria chambers. In the lower 50 meters of the limestone sections, there are indications of neomorphic processes, including the secondary grain-growth of micrite. Microstylolites and replacement veins of sparry calcite are also evident in the lower parts of the sections. Faunal composition and geologic setting indicate deposition in a deep-sea environment at depths that may have been close to the $\mathrm{CaCO}_{3}$ compensation depth. This may preclude the presence of metastable carbonate phases (aragonite and high $\mathrm{Mg}$-calcite) in the primary sediment. The limestones grade upward into indurated chalks and marls, and there is no evidence for uplift and exposure of the limestones to shallow-water or fresh-water conditions. Therefore, cementation in a deep-sea environment is indicated.

The pelagic limestones from Leg 15 are underlain by partly intrusive basalt flows, which contain included blocks of recrystallized carbonates, and by intrusive dolerites. The occurrence of repeated basaltic ash beds above the flows and sills implies a nearly simultaneous series of basaltic eruptions over a wide area in the Caribbean during Coniacian to early Santonian time (Donnelly et al., this volume). Lithified carbonate sediments dredged from the sea floor are often associated with submarine igneous rocks and vulcanogenic sediments (Saito et al., 1966; Cifelli et al., 1966; Thompson et al., 1968; Milliman, 1971). Bonatti (1966) has suggested that the occurrence of apparently authigenic calcite grains dispersed in pelagic zeolite clays in several cores from the Pacific can be attributed to the effects of local submarine igneous activity.

Submarine igneous activity can promote the cementation of carbonate sediments in several ways. First of all, an increase in temperature resulting from local igneous activity could lead to the precipitation of $\mathrm{CaCO}_{3}$ from interstitial pore water since the solubility of $\mathrm{CaCO}_{3}$ decreases with temperature. Submarine weathering of volcanics and of ash would lead to an increase of both $\mathrm{Ca}^{++}$concentration and $\mathrm{pH}$ value in pore waters, enhancing the possibility of carbonate precipitation. Another effect may be the dissolution of primary carbonate sediment by acidic volatiles degassing from magma, followed by the precipitation of

\footnotetext{
${ }^{1}$ Present address: Institute of Marine Sciences, University of Puerto Rico, Mayaguez, Puerto Rico.
}

$\mathrm{CaCO}_{3}$ after re-establishment of normal conditions. However, since the limestones show no evidence for dissolution on a large scale and since the original fabric is generally preserved, this effect is not indicated. Likewise, the general petrographic features of the limestone argue against extensive hydrothermal recrystallization or metamorphic alteration; the temperatures at which lithification occurred could not have been significantly higher than sedimentary temperatures.

While the emplacement of basement basalts and dolerites may have played an important role in the cementation of Coniacian to early Santonian limestones, other explanations are required for the younger (mid-Santonian to Maestrichtian) limestones. In this connection, Donnelly (History of circum-Caribbean volcanic activity, this volume) presents evidence for volcanic activity in the central Caribbean throughout the upper Cretaceous. However, lithification mechanisms which do not involve igneous activity may also have been involved (Milliman, 1966; Fischer and Garrison, 1967).

The isotope composition of submarine lithified carbonates can provide limits on the conditions under which lithification has occurred because recrystallization of the primary carbonate and precipitation of carbonate cement involved some degree of isotopic communication with ambient solutions. Isotope analyses may not only reflect the isotope composition of the water and of the dissolved carbonate species which exchange with the carbonate, but also, if carbonate-water oxygen isotope equilibrium can be demonstrated, provide an estimate of the temperature at which lithification occurred. Milliman (1966) has shown that lithification and recrystallization at the sea floor can in some cases result in oxygen isotope re-equilibration with cold bottom water of planktonic foraminiferal tests originally secreted in warm surface water and argues that this type of lithification is related to very low rates of sediment accumulation. Long periods of exposure to ambient bottom water and to the chemical gradients that exist in the sediment-water interface are apparently required. In contrast, most foraminifera show little or no tendency to re-equilibrate with pore water after burial (Emiliani, 1954). On the other hand, the oxygen isotope composition of other lithified carbonates dredged from the sea floor (including those associated with volcanics and volcanic detritus) are not compatible with reequilibration with bottom water, and suggest that lithification and recrystallization can also occur at different temperatures and/or in waters of different isotope compositions (Thompson et al., 1968; Milliman, 1971).

To aid in understanding the origin of the pelagic limestones from Leg 15, we measured the isotope abund- 
ances of carbon and oxygen in forty-two samples from the limestone sequences and the overyling chalks and marls from Sites 146, 152, and 153. The purpose of this study was to determine the extent to which the isotope compositions of the carbonates were altered from their original compositions by diagenetic processes. It was hoped that these isotopic data would provide information regarding the mechanisms of lithification of pelagic limestones, which are only rarely encountered in deep-sea sediments.

Isotope analyses of carbonates in bulk samples were carried out using the method described by McCrea (1950). Isotope compositions are reported in the $\delta$ notation relative to the PDB standard. The samples were examined optically in thin section and in stained and unstained acetate peels. Scanning electron microscopy was utilized for ultrastructure examination of the matrix. Detailed descriptions of the lithologies are given by Schneidermann (this volume) and in the core descriptions.

\section{RESULTS}

The isotope compositions and general petrographic features of the bulk samples are listed in Table 1. Most of the samples are from Sites 146 and 153, where in both cases limestones occur from about 600 meters to about 750 meters below bottom. The age of the limestone-chalk transition is Campanian-Maestrichtian at Site 146 and Maestrichtian-Paleocene at Site 153. At Site 152, which possibly is on an uplifted block, Cretaceous carbonates were encountered at shallower depths. No detailed isotopic study of carbonates from this site was undertaken, but one of the three samples analyzed from this site (Sample $152-23, \mathrm{CC})$ was the only sample we examined which showed some evidence for thermal metamorphism. It contains oriented pods of chlorite infilling a cavity and has a grayish red baked appearance. The matrix contains blotches of neomorphic microspar and pseudospar. Foraminifera tests, which are very abundant in this sample, are generally completely recrystallized. It was initially assumed that this carbonate would show the most profound isotopic effects of submarine vulcanism. This turned out not to be the case; we discuss this problem later.

Vertical profiles of isotope compositions (Figure 1) show that the abundances of both $\mathrm{O}^{18}$ and $\mathrm{C}^{13}$ in the limestones generally decrease with depth. The scatter in the oxygen isotope composition data is large, and there appear to be differences between Site 146 and Site 153 in the trend of $\delta \mathrm{O}^{18}$ with depth. In contrast, the trend of $\delta \mathrm{C}^{13}$ with depth is very regular at both sites.

The oxygen isotope compositions of the overlying unlithified carbonates (mostly from Site 146) show no comparable variation with depth. For the most part, the fluctuations in $\delta \mathrm{O}^{18}$ of these samples can be accounted for by fluctuations in temperature and in isotope composition of surface seawater. For the present surface waters of the Caribbean, the temperature range is $26 \pm 2^{\circ} \mathrm{C}$ (Sverdrup et al., 1942) and the $\delta \mathrm{O}^{18}$ (relative to SMOW) is $+1 \pm 0.5$ per mil (Epstein and Mayeda, 1953). Using the maximum correction of -0.6 per mil for nonglacial seawater, the predicted range of $\delta \mathrm{O}^{18}$ for $\mathrm{CaCO}_{3}$ in equilibrium with seawater under these conditions is $-1.6 \pm 1.2$ per mil (Craig, 1965). The oxygen isotope compositions of most of the unlithified carbonates are within this range. Thus, these values probably represent surface water conditions.

The $\delta \mathrm{C}^{13}$ values of Maestrichtian carbonates (chalks and marls at Site 146, limestones at Site 153) increase with depth by 1 to 2 per mil. J.R. Lawrence (personal communication) has found that the $\delta \mathrm{C}^{13}$ of carbonates from Site 149 increases by about 0.7 per mil from the Plio-Pleistocene to the Eocene. While these observations may suggest that the $\delta \mathrm{C}^{13}$ of Caribbean seawater has decreased from the Maestrichtian to the present, the possiblity that this trend is related to differences in the "vital" isotopic effects of the plant and animal bioclastics that constitute the bulk samples cannot be precluded.

The limestones are generally depleted in $\mathrm{O}^{18}$ relative to the unlithified carbonate sediments. In the upper part of the limestone sections, $\delta \mathrm{O}^{18}$ values generally range from -2.5 to -4.5 per mil. While higher surface temperatures during the upper Cretaceous (Lowenstam and Epstein, 1954; Lowenstam, 1964) may account for some of this "oxygen shift", isotopic alteration as a result of recrystallization and cementation is suggested. The more negative $\delta 0^{18}$ values $(-4$ to $-7 \%$ of limestones in the lower part of the sections cannot be accounted for by any reasonable manipulation of the temperature or isotope composition of surface seawater. Thus, we suggest that diagenesis related to cementation and recrystallization is responsible for the general decrease in $\delta \mathrm{O}^{18}$ with depth in the limestones.

Secondary calcite veins are found in the lower 50 meters of the limestone sections at sites 146 and 153 . The oxygen isotope composition ( -8.3 per mil) of calcite recovered from a vein in 146-38R-1 is at least 1 to 2 per mil lighter than the surrounding limestones, suggesting that some of the "oxygen shift" in these limestones may be related to the occurrence of secondary carbonates (perhaps including sparry infillings, cement, and recrystallized micrite) in the bulk samples. It is likely that the oxygen isotope composition of this vein, rather than the compositions of the bulk samples, more accurately reflects the conditions under which diagenesis occurred because the secondary carbonates were evidently precipitated directly from pore solutions whereas the bulk carbonates have been only partially recrystallized. In the latter case, lack of isotope equilibrium or relatively low water/carbonate ratios in the carbonate-water system may have produced an "oxygen shift" that was less than the maximum attainable value. The further significance of isotopically-light secondary carbonate is suggested by the texture and isotope composition of Sample 152-22-2. This sample was the only representative of "normal" pelagic limestone from Site 152 that we analyzed. Although it occurs only some 10 meters above the basalt basement, it has the textural features (lack of replacement veins and of grain growth of micrite) and the isotope composition typical of limestones from the upper part of the sections at Sites 146 and 153. The implication is that oxygen isotope alteration of the limestones near the basement at these sites may have been the result of exchange with solutions from which secondary calcites were crystallized.

The $\delta \mathrm{C}^{13}$ values of the limestones from Sites 146 and 153 decrease from a maximum of about +3 per mil near the top of the sections to 0 to +1 per mil near the basement. 
TABLE 1

Isotope Composition of Submarine Limestones, Leg 15

\begin{tabular}{|c|c|c|c|c|c|c|}
\hline Sample & $\begin{array}{l}\text { Depth } \\
(\mathrm{m})\end{array}$ & Age & $\begin{array}{c}\delta \mathrm{O}^{18} \\
\text { (per mil) }\end{array}$ & $\begin{array}{c}\delta \mathrm{C}^{13} \\
\text { (per mil) }\end{array}$ & $\begin{array}{c}\mathrm{CO}_{2} \text { yield } \\
(\mu \mathrm{M} / \mathrm{mgm} \text { Sample })\end{array}$ & Description \\
\hline $146-2-6(106)$ & 262 & Miocene & -0.54 & +1.44 & 5.41 & $\begin{array}{l}\text { Radiolarian-rich nannoplankton } \\
\text { marl }\end{array}$ \\
\hline $146-5-1$ & 423 & Eocene & -1.36 & +1.58 & 6.76 & $\begin{array}{l}\text { Foraminifera-nannoplankton } \\
\text { chalk }\end{array}$ \\
\hline $146-11-1(128-132)$ & 477 & $\begin{array}{l}\text { Paleocene- } \\
\text { Maestrichtian }\end{array}$ & -0.73 & +1.09 & 3.29 & $\begin{array}{l}\text { Bioturbated, compacted } \\
\text { foraminifera marl }\end{array}$ \\
\hline $146-11(\mathrm{CC})$ & 488 & Maestrichtian & -2.78 & +1.99 & 3.41 & Nannoplankton chalk \\
\hline $146-13-3(144-145)$ & 497 & Maestrichtian & -2.66 & +2.28 & 2.51 & $\begin{array}{l}\text { Foraminifera-nannoplankton } \\
\text { marl }\end{array}$ \\
\hline $146-15(\mathrm{CC})$ & 521 & Maestrichtian & -1.78 & +2.61 & 4.67 & Nannoplankton marl \\
\hline $146-19(C C)$ & 557 & Maestrichtian & -1.95 & +3.07 & 6.80 & $\begin{array}{l}\text { Foraminifera-nannoplankton } \\
\text { chalk }\end{array}$ \\
\hline $146-23-2(23.5-25)$ & 587 & Campanian & -2.22 & +3.09 & 7.98 & Nannoplankton chalk \\
\hline $146-26-2(78-82)$ & 613 & Campanian & -3.35 & +3.01 & 6.24 & Nannoplankton chalk \\
\hline $146-27-1(0-10)$ & 620 & Campanian & -3.83 & +2.93 & 6.70 & $\begin{array}{l}\text { Laminated fossilferous } \\
\text { micrite }\end{array}$ \\
\hline $146-27-1(129-131)$ & 620 & Campanian & -2.86 & +3.19 & 7.57 & $\begin{array}{l}\text { Laminated argillaceuous- } \\
\text { fossiliferous micrite }\end{array}$ \\
\hline $146-28-2(18-22)$ & 631 & Campanian & -4.98 & +2.82 & 3.05 & $\begin{array}{l}\text { Silicified, almost packed, } \\
\text { radiolarian biomicrite }\end{array}$ \\
\hline 146-29(CC) & 647 & Santonian & -3.97 & +2.04 & 4.84 & Radiolarian biomicrite \\
\hline $146-30-4(50-52)$ & 652 & Santonian & -2.60 & +2.90 & 4.92 & $\begin{array}{l}\text { Partly silicified, sparse } \\
\text { foraminifera-radiolarian } \\
\text { biomicrite }\end{array}$ \\
\hline $146-31-3(16-19)$ & 661 & Santonian & -3.75 & +2.99 & 6.26 & $\begin{array}{l}\text { Partly silicified, sparse } \\
\text { foraminifera-radiolarian } \\
\text { biomicrite }\end{array}$ \\
\hline $146-32(\mathrm{CC})$ & 674 & Santonian & -3.28 & +2.81 & 6.17 & $\begin{array}{l}\text { Sparse foraminifera calcified } \\
\text { radiolarian biomicrite }\end{array}$ \\
\hline $146-33-1(102-105)$ & 675 & Santonian & -4.38 & +2.61 & 4.64 & $\begin{array}{l}\text { Partly silicified radiolarian } \\
\text { biomicrite }\end{array}$ \\
\hline $146-35-2(147.5-150)$ & 695 & Santonian & -5.49 & +2.15 & 7.57 & $\begin{array}{l}\text { Sparse to packed calcified } \\
\text { radiolarian biomicrite }\end{array}$ \\
\hline $146-35(C C)$ & 701 & Santonian & -5.69 & +2.03 & 5.52 & $\begin{array}{l}\text { Laminated sparse calcified } \\
\text { radiolarian and foraminifera } \\
\text { biomicrite }\end{array}$ \\
\hline $146-36 R-2(84-86)$ & 705 & Santonian & -6.52 & +2.07 & 4.88 & $\begin{array}{l}\text { Partly silicified sparse to packed } \\
\text { foraminifera and radiolarian } \\
\text { biomicrite (replacement veins) }\end{array}$ \\
\hline 146-38R-1(113-115) & 715 & Santonian & -5.59 & +1.00 & 4.33 & $\begin{array}{l}\text { Sparse calcified radiolarian } \\
\text { biomicrite }\end{array}$ \\
\hline $\begin{array}{l}\text { Calcite vein from } \\
\qquad 146-38 \mathrm{R}-1(130-133)\end{array}$ & & Santonian & -8.27 & +0.97 & 9.77 & Replacement vein, sparry calcite \\
\hline $146-39 R-2(22-24)$ & 721 & Santonian & -6.82 & +0.84 & 6.84 & $\begin{array}{l}\text { Packed foraminifera biomicrite; } \\
\text { microstylolites }\end{array}$ \\
\hline $146-41 \mathrm{R}-2(114-116)$ & 740 & Coniacian & -5.68 & +1.30 & 8.32 & $\begin{array}{l}\text { Slightly metamorphosed and } \\
\text { packed foraminifera biomicrite }\end{array}$ \\
\hline $152-4-3(108-119)$ & 186 & Paleocene & -1.53 & +2.74 & 4.73 & $\begin{array}{l}\text { Partly silic. foraminifera- } \\
\text { nannoplankton chalk }\end{array}$ \\
\hline $152-22-2(45)$ & 464 & Campanian & -3.30 & +2.71 & 6.41 & Packed foraminifera biomicrite \\
\hline $152-23(C C)$ & 474 & Campanian & -0.81 & +1.03 & 8.52 & $\begin{array}{l}\text { Slightly metamorphosed } \\
\text { packed foraminifera biomicrite }\end{array}$ \\
\hline $153-6-2(132-133)$ & 415 & Miocene & -0.45 & +2.45 & 8.43 & Nannoplankton chalk \\
\hline $153-10-2(146-150)$ & 594 & Paleocene & -3.44 & +2.36 & 2.11 & Calcified radiolarian micritic marl \\
\hline $153-12-1(104-108)$ & 610 & $\begin{array}{l}\text { Paleocene- } \\
\text { Maestrichtian }\end{array}$ & -0.94 & +1.84 & 2.14 & Hard ground, limestone breccia \\
\hline $153-12-1(136-139)$ & 610 & Maestrichtian & -0.64 & +2.11 & 1.12 & $\begin{array}{l}\text { Packed foraminifera argillaceuous } \\
\text { biomicrite }\end{array}$ \\
\hline $153-13-2(30-33)$ & 621 & Maestrichtian & -3.44 & +2.01 & 6.57 & Sparse argillaceuous biomicrite \\
\hline $153-14-1(113-115)$ & 657 & Maestrichtian & -2.48 & +2.90 & 8.99 & $\begin{array}{l}\text { Sparse to packed foraminifera } \\
\text { biomicrite }\end{array}$ \\
\hline $153-15-1(27-30)$ & 667 & Maestrichtian & -3.67 & +2.65 & 7.57 & $\begin{array}{l}\text { Sparse to packed foraminifera- } \\
\text { radiolarian biomicrite; }\end{array}$ \\
\hline $153-15-3(30-34)$ & 670 & Maestrichtian & -3.46 & +2.40 & 7.92 & $\begin{array}{l}\text { microcrosslaminations, } \\
\text { microstylolites, volcanic ash } \\
\text { layers throughout; slightly }\end{array}$ \\
\hline $153-15-3(67-69)$ & 670 & Maestrichtian & -2.80 & +2.37 & 6.47 & silicified; replacement veins \\
\hline
\end{tabular}


TABLE 1 - Continued

\begin{tabular}{|c|c|c|c|c|c|c|}
\hline Sample & $\begin{array}{l}\text { Depth } \\
\text { (m) }\end{array}$ & Age & $\begin{array}{c}\delta \mathrm{O}^{18} \\
\text { (per mil) }\end{array}$ & $\begin{array}{c}\delta \mathrm{C}^{13} \\
\text { (per mil) }\end{array}$ & $\begin{array}{c}\mathrm{CO}_{2} \text { yield } \\
(\mu \mathrm{M} / \mathrm{mgm} \text { Sample })\end{array}$ & Description \\
\hline 153-15(CC) & 731 & Coniacian & -4.00 & +1.48 & 7.80 & $\begin{array}{l}\text { Sparse foraminifera biomicrite; } \\
3-4 \text { thin replacement veins }\end{array}$ \\
\hline $153-16-2(0-4)$ & 732 & Coniacian & -7.10 & +1.13 & 6.58 & Phosphatic calcareous clay \\
\hline $153-16(C C)$ & 740 & Coniacian & -5.85 & +0.81 & 5.70 & $\begin{array}{l}\text { Sparse to packed radiolarian- } \\
\text { foram. biomicrite; bioturbated } \\
\text { with lithoclasts of organic clay }\end{array}$ \\
\hline $153-17-1(130-132)$ & & Coniacian & -4.58 & +0.24 & 5.91 & $\begin{array}{l}\text { Limestone interbedded with } \\
\text { volcanic clay }\end{array}$ \\
\hline $153-18-1(143-145)$ & & Coniacian & -4.73 & +0.39 & 8.93 & $\begin{array}{l}\text { Sparse foraminifera biomicrite; } \\
\text { glauconite }\end{array}$ \\
\hline $153-18-2(82-83)$ & & Coniacian & -3.45 & -0.81 & 1.26 & $\begin{array}{l}\text { Volcanic ash, silt and clay; rare } \\
\text { nannoplankton and foraminifera }\end{array}$ \\
\hline
\end{tabular}

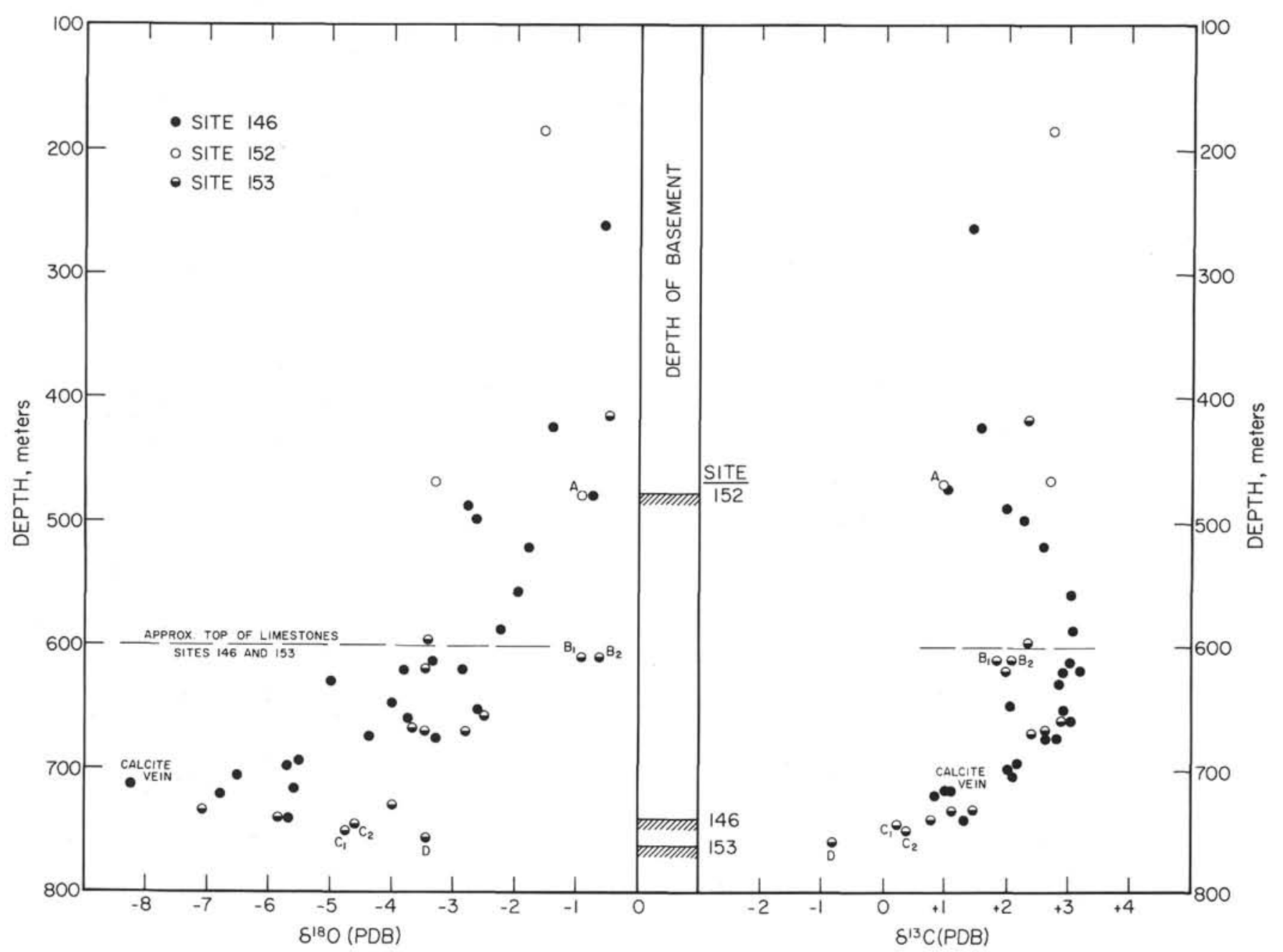

Figure 1. The vertical distribution of isotope compositions of carbonate samples from Sites 146, 152, and 153. All isotope analyses determined in this study are shown. The depth of the basement at all sites and the approximate top of the limestones sections at Sites 146 and 153 are indicated. Note that $\delta O^{18}$ and $\delta C^{13}$ values in the limestones generally decrease with depth. Samples which do not appear to fit either of the trends shown here or the correlation of $\delta O^{18}$ and $\delta C^{13}$ in Figure 2 are identified by capital letters and are discussed in the text. 
This trend may simply represent fluctuations in the initial carbon isotope composition of the primary sediment. Alternatively, the observation that both $\mathrm{C}^{13}$ and $\mathrm{O}^{18}$ abundances decrease with depth suggests the possibility that those limestones for which oxygen isotope alteration is clearly indicated may also have undergone carbon isotope alteration. The carbon isotope composition of the secondary carbonate vein described above $(+1.0$ per mil) is essentially identical to the composition of the surrounding limestones. Thus, the occurrence of secondary carbonate in the lower limestones does not explain their relatively low $\delta \mathrm{C}^{13}$ values. This may suggest that the carbon isotope composition of dissolved inorganic carbon in the pore waters from which secondary carbonates were crystallized was controlled by the bulk carbonates. In other words, the trend in $\delta \mathrm{C}^{13}$ in the limestones may not be related to the diagenetic processes which led to the development of secondary carbonates. Alternatively, extensive isotope exchange between the bulk carbonates and dissolved inorganic carbon, whose isotope composition was controlled at least in part by other carbon reservoirs, would also result in similar $\delta \mathrm{C}^{13}$ values for both secondary carbonates and bulk samples. If, in fact, carbon isotope alteration of the lower limestones has occurred, then an external reservoir of isotopically light carbon was evidently involved.

A consequence of the decrease in both $\delta \mathrm{O}^{18}$ and $\delta \mathrm{C}^{13}$ with depth in the limestones is the observation that the isotope composition of most of the limestones define a fairly restricted composition field (Figure 2). There are several samples from Sites 152 and 153 which fall outside this field. These samples, identified by capital letters in Figures 1 and 2, when compared to the general vertical trends of isotope composition, appear to be somewhat enriched in $0^{18}$. Special explanations will evidently be required to account for these apparently anomalous compositions; some possibilities are considered in the following section.

\section{DISCUSSION}

\section{Interpretation of Oxygen Isotope Compositions}

Deep-sea carbonates which have been lithified at the sea floor may in some cases be distinguishable on the basis of oxygen isotope composition. Recrystallized and lithified foraminiferal oozes (Late Miocene and Plio-Pleistocene) from nonvolcanic seamounts and slope limestones composed of both pelagic bioclastics and displaced shallowwater debris have oxygen isotope compositions (Figure 2) which are in equilibrium with present bottom water (Milliman, 1966; 1971). This indicates that cementation and recrystallization occurred in situ. The oxygen isotope composition of foraminifera-rich carbonate veins, carbonate concretions, and dissemenated carbonates in submarine basalts from the Mid-Atlantic Ridge are generally compatible with those in equilibrium with present bottom water (Muehlenbachs, 1971). However, Thompson et al (1968) point out that consolidated oozes (early Eocene and late Miocene) collected at depths of 1800 to 4200 meters in the vicinity of St. Paul's Rocks have not completely re-equilibrated with bottom water in spite of the fact that these samples were exposed to such water for long periods.

It is evident that the oxygen isotope compositions of pelagic limestones from Leg 15 are not consistent with lithification at the sea floor. Assuming that bottom water temperatures during the upper Cretaceous were as high as 10 to $20^{\circ} \mathrm{C}$ (Lowenstam, 1964) and using Craig's (1965) estimate of -0.5 per mil (relative to SMOW) for average nonglacial seawater, carbonates that equilibrated with bottom water during the upper Cretaceous should have $\delta \mathrm{O}^{18}$ values in the range $-1 \pm 0.5$ per mil; most of the limestones are considerably more isotopically negative than this range. Two of the so-called anomalous samples, 153-12-1-(104-108) ( $\mathrm{B}_{1}$ in Figures 1 and 2$)$ and 153-12-1(136-139) ( $B_{2}$ in Figures 1 and 2 ) have oxygen isotope compositions ( -0.9 and -0.6 , respectively) within this range. These samples occur at the top of the limestones section at Site 153 and appear to span the Cretaceous-Tertiary boundary; presumably, they represent the missing time interval of Late Maestrichtian to earliest Paleocene. They are partly silicified marls, limestones, and limestone breccias with sparry calcite infilling fractures and cementing clasts together. A highly indurated chalk, Sample 146-11-1-(128-132), also occurs at the Cretaceous-Tertiary boundary at Site 146. These samples have textures similar to the "hardgrounds" which often occur at the CretaceousTertiary boundary at other locations (Worsley, 1970) and may be comparable to the lithified carbonate crusts that form during periods of nondeposition (Milliman, 1966; Fischer and Garrison, 1967). Thus, the environment in which these crusts were cemented and recrystallized may have been quite different than the corresponding environment for the pelagic limestones. The oxygen isotope data suggest this possibility.

The pelagic limestones differ from the sea floor carbonate crusts in other ways. The deposition of carbonate sediment was apparently continuous throughout the upper Cretaceous in the central Caribbean, and hence sediments were exposed to bottom water for relatively short periods of time. The pelagic limestones from Leg 15 are more texturally similar to "normal" pelagic limestones from continental areas than to submarine lithified crusts. This similarity suggests that some caution should be exercised in interpreting the oxygen isotope composition of young pelagic limestones. It is commonly accepted that low $\delta \mathrm{O}^{18}$ values in young marine carbonates reflects diagenetic alteration in isotopically-light meteoric water (Friedman, 1964; Gross, 1964). The results presented here demonstrate that deep-sea carbonates that have almost certainly never been exposed to freshwater may also have low $\delta \mathrm{O}^{18}$ values. Thus, the oxygen isotope composition of young pelagic carbonate rocks may not unambiguously reflect their environment of diagenesis and lithification.

The trend of $\delta \mathrm{O}^{18}$ in the limestones is consistent with isotope equilibrium between carbonates and marine pore waters at temperatures that increase with depth. The reference temperature scale plotted in Figure 2 indicates that the lower limestones and the secondary calcite vein are in equilibrium with water having $\delta \mathrm{O}^{18}$ (relative to SMOW) $=0$ per mil at about $50^{\circ} \mathrm{C}$ and $60^{\circ} \mathrm{C}$, respectively. Since we have no way of independently estimating the isotope 


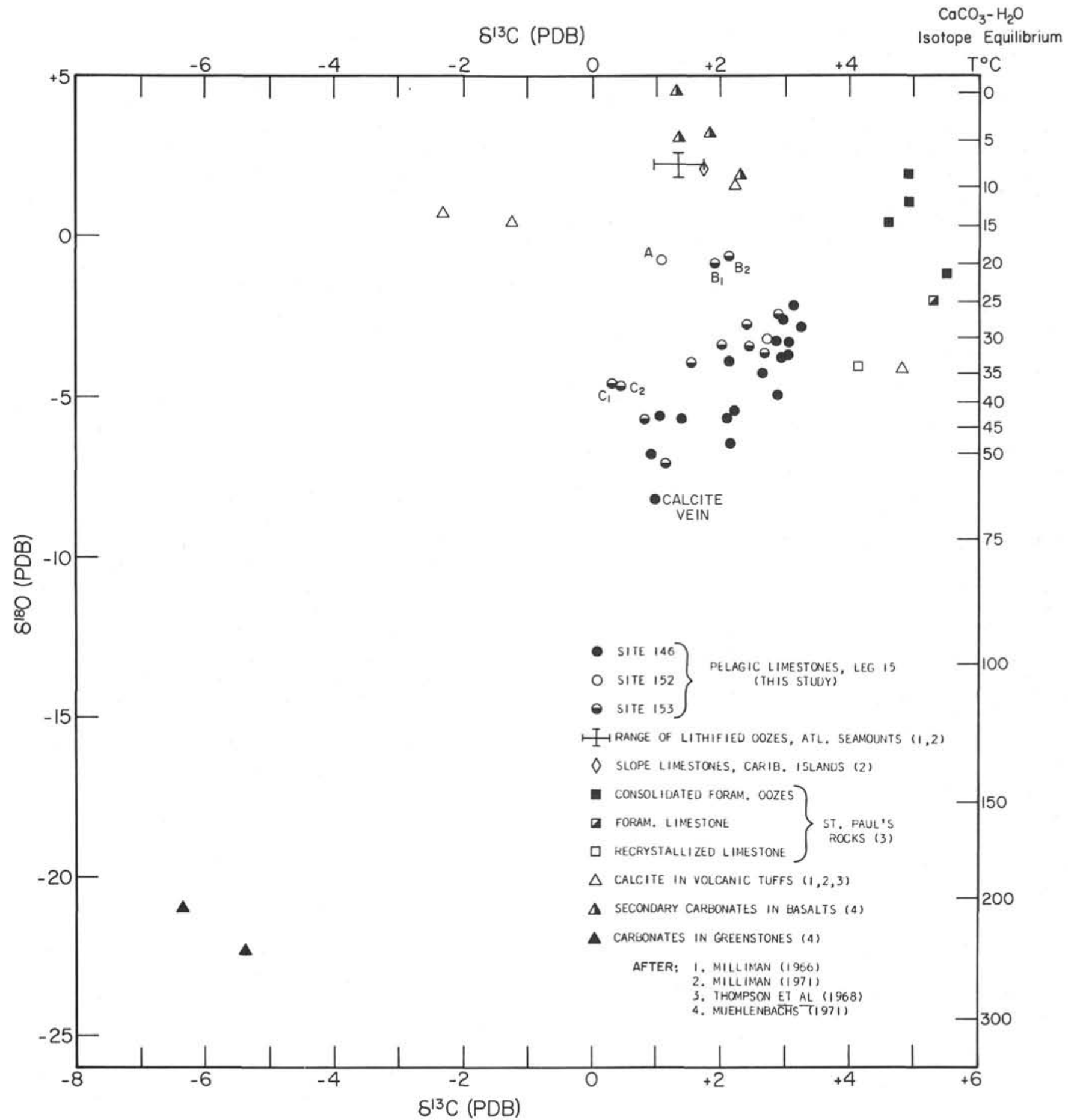

Figure 2. The isotope compositions of pelagic limestones from Sites 146, 152, and 153 and of other submarine carbonates.

The carbon and the oxygen isotope compositions of the pelagic limestones from Leg 15 appear to be correlated in a roughly linear trend. Samples which do not fit this trend are identified by capital letters and are discussed in the text. The temperature scale corresponds to oxygen isotope equilibrium between water of $\delta O^{18}$ (relative to SMOW) 0 and calcite (Craig, 1965; O’Neil et al, 1969).

composition of pore waters which exchanged with the carbonates, the relative proportions of water and carbonate that exchanged, or if equilibrium was achieved in all cases, any estimate of isotopic temperature is uncertain. Nonetheless, the temperatures indicated in Figure 2 are not incompatible with the petrographic evidence for moderate diagenetic alteration of the limestones.
Isotope exchange after lithification in a normal geothermal gradient may also be a contributing factor to the "oxygen shift" in the limestones. If post-lithification exchange were pervasive, then it is possible that the original oxygen isotope record of the lithified carbonates may have been obiliterated. Thus, it is important to consider the possibility that re-equilibration at in situ temperatures may 
be responsible for the "oxygen shift" in the limestones. The present average heat flow in the central Caribbean is $1.3 \times 10^{-6} \mathrm{cal} / \mathrm{cm}^{2}-\mathrm{sec}$ (Epp et al., 1970). Assuming that the unlithified sediments overlying the limestones have an average thermal conductivity of $2.5 \times 10^{-3} \mathrm{cal} /{ }^{\circ} \mathrm{C}-\mathrm{cm}-\mathrm{sec}(\mathrm{a}$ fairly typical value for marine clays and oozes), then the increase in temperature from the sea floor to the top of the limestones $(600 \mathrm{~m})$ is about $30^{\circ} \mathrm{C}$. Assuming that the limestones have a thermal conductivity two to three times that of the unlithified sediments, then the temperature at the base of the limestone sections $(750 \mathrm{~m})$ is only $3^{\circ} \mathrm{C}$ higher. This temperature gradient corresponds to a maximum change of only -1.2 per mil in the $\delta 0^{18}$ of calcite in equilibrium with sea water of a constant isotope composition. Thus, a normal geothermal gradient cannot account for the "oxygen shift" in the limestones unless there is a corresponding decrease with depth in the $\delta \mathrm{O}^{18}$ of pore water. We estimate that for equilibrium under in situ temperatures, the pore water in the limestones must vary from $0.0 \pm 1.0$ per mil (relative to SMOW) at the top of the sections to $-1.5 \pm 1.5$ near the base of the sections. The latter range is generally more negative than Craig's (1965) sstimate of average nonglacial seawater. However, J. R. Lawrence (personal communication) has recently determined that the $\delta \mathrm{O}^{18}$ of pore water at several horizons in Site 149 is 2 to 3 per mil lighter than SMOW. Although it may be difficult to explain the origin of this light pore water, these data imply that it is not possible to entirely dismiss re-equilibration at in situ temperatures as a major factor in the "oxygen shift" of the limestones.

We point out, however, that this interpretation does not account for the abrupt change in the trend of $\delta \mathrm{O}^{18}$ with depth at the transition between chalk-marls and limestones. If isotopic alteration at depth is controlled by the temperature of burial, then we should expect a more continuous decrease of $\delta \mathrm{O}^{18}$ with depth across the transition. Rather, the oxygen isotope data suggest to us that the unlithified carbonates have generally retained their original compositions, and only those carbonates which have been cemented and lithified have undergone oxygen isotope exchange.

We interpret the oxygen isotope evidence to indicate that cementation and recrystallization of the limestones occurred during a period of high temperature in the sediments, such as during a time of abnormally high heat flow. The widespread volcanic activity in the Caribbean region throughout the upper Cretaceous is probably significant in this regard, and may explain why no pelagic limestones younger than upper Cretaceous were encountered at these sites. Oxygen isotope alteration and textural evidence for the remobilization of carbonate is most apparent in the limestones of Turonian to early Santonian age. This time period correlates with the ages inferred by Donnelly et al (this volume) for widespread basaltic vulcanism in the central Caribbean, including the emplacement of the local basalt and dolerite basements. The occurrence of younger pelagic limestones, and the fact that their oxygen isotope compositions are not compatible with equilibrium with cold water, suggests that elevated temperatures prevailed in the sediment column after the emplacement of the local basement. The observation that the uppermost limestones at Site 153 are younger than the comparable limestones at Site 146 may be explained by the continuation of volcanic activity into the Paleocene in the western Caribbean (Donnelly, History of circum-Caribbean volcanic activity, this volume). The general scarcity of pressure welding and other compaction features in the limestones implies that cementation occurred at shallow depths of burial; this would be consistent with lithification shortly after deposition.

Several bulk carbonates from near the basement at Sites 152 (point $A$ in Figures 1 and 2, the previously described metamorphosed carbonate) and 153 (points $C_{1}, C_{2}$, and D) have anomalously high $\delta \mathrm{O}^{18}$ values. This situation is puzzling since exchange at elevated temperatures should have resulted in a large "oxygen shift" in the negative direction. Kinetic isotope effects during thermal metamorphism of carbonates are also in the negative direction (Shieh and Taylor, 1969). Exchange with isotopically positive water of 6 to 7 per mil (relative to SMOW) emanating from basaltic magma is a possible explanation. However, recent investigations (Wenner, 1970; Muehlenbachs, 1971) have found little evidence for hydrothermal or metamorphic alteration of submarine igneous rocks by isotopically-positive water. It is also difficult to understand why low-temperature exchange would have selectively altered only these carbonates and not the overlying carbonates as well. Figure 2 shows that the isotope compositions of other submarine lithified carbonates associated with igneous rocks and tuffs are widely scattered. Thus, on the basis of the limited data available, we tentatively conclude that no systematic relationship between the isotope compositions of such lithified carbonates may exist; such factors as nonequilibrium isotope effects, interaction with magmatic water, later diagenesis, and other local environmental factors may to a variable degree influence the isotope composition of these carbonates.

\section{Interpretation of the Carbon Isotope Compositions}

The carbon isotope compositions of the limestones are generally within the range of compositions for younger, unlithified carbonates and also of apparently unaltered upper Cretaceous chalks analyzed by Lowenstam and Epstein (1954). Thus, the systematic variation of $\delta \mathrm{C}^{13}$ with depth in the limestones may simply be due to variations in the initial composition of the bioclastic components. However, the observation that the carbon and the oxygen isotope compositions of the limestones are generally correlated (Figure 2) suggests to us that the trend in $\delta \mathrm{C}^{13}$ with depth may be due to diagenetic alteration.

Isotopically negative carbon has been reported by Muehlenbachs (1971) in carbonates disseminated in submarine greenstones (Figure 2). Oxygen isotope fractionations between calcite and other minerals in these rocks suggests that the $\mathrm{CaCO}_{3}-\mathrm{H}_{2} \mathrm{O}$ temperatures shown on Figure 2 for these carbonates are probably valid. Thus, isotopically-light carbon may occur in submarine carbonates that have undergone or are the result of high-temperature alteration. Muehlenbachs (1971) suggests that the carbon isotope composition of the carbonates in submarine greenstones can be attributed to either of two factors: (1) kinetic isotope effects during metamorphic decarbonation, or 
(2) an invasion of isotopically-negative "juvenile" carbon of -5 to -8 per mil. However, in order to account for $\mathrm{C}^{13}$ depletion in the pelagic limestones by either of these two mechanisms, extensive recrystallization and perhaps some replacement of carbonate minerals is required. There is little evidence for such alteration in the samples we studied. Thus, although the isotope compositions of the carbonates in submarine greenstones lie surprisingly close to an extension of the linear composition trend of the pelagic limestones, this relationship may be coincidental. It should be noted, however, that the carbon and oxygen isotope compositions of successive generations of hydrothermal calcite show a similar linear trend (Rye, 1966; Hall and Friedman, 1969).

Isotope exchange between the limestones and dissolved inorganic carbon in pore water that was relatively depleted in $\mathrm{C}^{13}$ is another possible explanation. Inasmuch as equilibrium isotope exchange between solid $\mathrm{CaCO}_{3}$ and dissolved $\mathrm{HCO}_{3}^{-}$(the principal carbonate species in seawater) is not very temperature sensitive in the range 20 to $60^{\circ} \mathrm{C}$ (Emrich et al, 1970), variations in the $\delta \mathrm{C}^{13}$ of carbonates would probably be mostly due to differences in the extent of exchange and perhaps to a decrease with depth in the $\delta \mathrm{C}^{13}$ of dissolved $\mathrm{HCO}_{3}^{-}$. The most likely source of isotopically-light dissolved $\mathrm{HCO}_{3}^{-}$is oxidizing organic matter, which has a $\delta \mathrm{C}^{13}$ of about -20 per mil (Degens, 1969). The $\delta \mathrm{C}^{13}$ values of $\mathrm{HCO}_{3}^{-}$in deep sea water are in the range -1 to $+1 \%$ (Deuser and Hunt, 1969; Craig, 1970; Kroopnick et al., 1970). Presley and Kaplan (1972) note that the $\delta \mathrm{C}^{13}$ values at shallow subbottom depths in DSDP cores where very high concentrations of total dissolved $\mathrm{CO}_{2}$ are found reflect contributions from biological sources. They also observe that there is a tendency for dissolved $\mathrm{CO}_{2}$ to become isotopically heavy with depth in the sediment column and tentatively suggest that this is related to exchange with solid carbonate phases and hydrocarbon gases. The decrease in $\delta \mathrm{C}^{13}$ values with depth in the limestones may reflect such an isotope exchange mechanism. Moreover, we observed that those limestones in the lower part of the sections which appear to contain the highest amounts of organic matter also had the lowest $\delta \mathrm{C}^{13}$ values.

It is noteworthy that alteration of the carbon isotope composition of the limestones by exchange with pore water carbonate requires extensive flushing of the sediment by fresh pore water during the recrystallization-lithification episode. This implication arises from the assumption that the carbon reservoir of the carbonate sediment was much larger than the carbon reservoir of interstitial pore waters. For a saturated porosity of 50 percent and a concentration of total $\mathrm{CO}_{2}$ equal to that of average seawater, the molar ratio of carbon in solution to carbon in carbonates is about $10^{-4}$. Even if the total $\mathrm{CO}_{2}$ concentration in pore water was ten times that in average seawater and all dissolved $\mathrm{CO}_{2}$ were derived from oxidized organic matter (i.e., $\delta \mathrm{C}^{13} \cong-20$ per mil), it is easily shown that a decrease in $\delta \mathrm{C}^{13}$ of the solid carbonate by 1 per mil requires equilibration with ten to fifty pore volumes for porosities of 80 and 40 percent, respectively. It is possible that the emplacement of local basement could have produced thermal convection of heated pore waters. This may explain why the older limestones have $\delta \mathrm{C}^{13}$ values which decrease markedly with depth, while the $\delta \mathrm{C}^{13}$ values in the younger limestones show little variation and may in fact represent the initial composition of the primary carbonate.

\section{CONCLUSIONS}

This isotope study of upper Cretaceous pelagic limestones from the central Caribbean has shown that both the $\delta \mathrm{O}^{18}$ and the $\delta \mathrm{C}^{13}$ values of limestones from Sites 146 and 153 decrease from the top to the base of the sections. The extent of this "oxygen shift" cannot be attributed to variations in temperature or isotope composition of surface seawater. Moreover, since the overlying unlithified carbonates have oxygen isotope compositions that are compatible with surface conditions, cementation and recrystallization of the limestones are apparently the principal factors causing the "oxygen shift." Lithification at the sea floor should have resulted in an isotope shift in the positive direction; hence, this mechanism is inconsistent with the data. Re-equilibration of the limestones with pore waters in the present geothermal gradient can only account for the "oxygen shift" if there is a corresponding decrease with depth in the $\delta 0^{18}$ of pore water. In light of recent analyses of pore water from Site 149, this possibility cannot be dismissed. An alternative interpretation of the oxygen isotope data (and the one that we favor) is that cementation and recrystallization occurred during a period of high temperatures in the pelagic sediments. The chronology of upper Cretaceous volcanic activity in the Caribbean suggests that lithification may have occurred throughout this period. Cementation at shallow depths of burial is compatible with the general textural features of the limestones. Since the range of carbon isotope compositions in the limestones is generally within the range of unaltered marine carbonates, the trend of $\delta \mathrm{C}^{13}$ with depth may not reflect diagenetic alteration. However, the observation that low $\delta \mathrm{C}^{13}$ values correlate with strongly negative $\delta \mathrm{O}^{18}$ values suggests this possibility. Isotope exchange between the carbonate constituents of the limestones and dissolved inorganic carbon in pore waters that was derived in part from oxidizing organic matter is the most reasonable explanation for a diagenetically-controlled "carbon shift". However, any mechanism of carbon isotope alteration by exchange with dissolved species seems to require considerable flushing of pore water through the sediment.

\section{ACKNOWLEDGMENTS}

The senior author wishes to acknowledge the financial support provided by the National Science Foundation through the grant NSF GA-1680. Mr. L. R. Lewis drafted the figures.

\section{REFERENCES}

Bonatti, E., 1966. Deep-sea authigenic calcite and dolomite. Science. 153, 534 .

Cifelli, R., Bowen, V. T. and Siever, R., 1966. Cemented foraminiferal oozes from the mid-Atlantic Ridge. Nature. 209, 32.

Craig, H., 1965. The measurement of oxygen isotope paleotemperatures. Proc. Spoleto Conf. Stable Isotopes Oceanog. Studies Paleotemp., 1965. 3.

1970. Abyssal carbon 13 in the South Pacific. J. Geophys. Res. 75, 69 . 
Degens, E. T., 1969. Biogeochemistry of stable carbon isotopes. In Eglinton, G. and Murphy, M. T. J., 1969. Organic Geochemistry. (Springer-Verlag). 304.

Deuser, W. G. and Hunt, J. M., 1969. Stable isotope ratios of dissolved inorganic carbon in the Atlantic. Deep-Sea Res. 16, 221.

Emiliani, C., 1954. Depth habitats of some species of pelagic foraminifera as indicated by oxygen isotope ratios. Am. J. Sci., 252, 149.

Emrich, K., Ehhalt, D. H. and Vogel, J. C., 1970. Carbon isotope fractionation during the precipitation of calcium carbonate. Earth Planet Sci. Lett. 8, 363.

Epp, D., Grim, P. J. and Langseth, M. G., Jr., 1970. Heat flow in the Caribbean and Gulf of Mexico. J. Geophys. Res. 75, 5655.

Epstein, S. and Mayeda, T. K., 1953. Variations of the $\mathrm{O}^{18} / \mathrm{O}^{16}$ ratio in natural waters. Geochem. Cosmochim Acta. 4, 213.

Fischer, A. G. and Garrison, R. E., 1967. Carbonate lithification on the sea floor. J. Geol. 75, 488.

Friedman, G. M., 1964. Early diagenesis and lithification in carbonate sediments. J. Sediment Petrol. 34, 777.

Gross, M. G., 1964. Variations in the $\mathrm{O}^{18} / \mathrm{O}^{16}$ and $\mathrm{C}^{13} / \mathrm{C}^{12}$ ratios of diagenetically altered limestones in the Bermuda Islands. J. Geol. 72, 170.

Hall, W. E. and Friedman, I., 1969. Oxygen and carbon isotopic composition of ore and host rock of selected Mississippi Valley deposits. USGS Prof. Paper 650-C, C-140.

Kroopnick, P., Deuser, W. G. and Craig, H., 1970. Carbon 13 Measurements on dissolved inorganic carbon at the North Pacific (1969) Geosecs. station. J. Geophys. Res. 75, 7668 .

Lowenstam, H. A., 1964. Paleotemperatures of the Permian and Cretaceous period. In Nairn, E. M., 1964. Problems in Paleoclimatology. (Interscience). 227.

Lowenstam, H. A. and Epstein, S., 1954. Paleotemperatures of the Post-Aptian Cretaceous as determined by the oxygen isotope method. J. Geol. 62, 207.
McCrea, J. M., 1950. The isotopic chemistry of carbonates and a paleotemperature scale. J. Chem. Phys. 18, 849 .

Milliman, J. D., 1966. Submarine lithification of carbonate sediments. Science. 153, 994. 1971. Carbonate lithification in the deep sea. In Bricker, O. P., 1971. Carbonate Cements. Johns Hopkins Univ. Studies in Geology, No. 19.

Muehlenbachs, K., 1971. Oxygen isotope studies of rocks from mid-ocean ridges. Ph.D. thesis, University of Chicago.

O'Neil, J. R., Clayton, R. N., and Mayedo, T. K., 1966. Oxygen isotope fractionation in divalent metal carbonates. J. Chem. Phys. 51, 5547.

Presley, B. J. and Kaplan, I. R., 1972. Interstitial water chemistry: Deep Sea Drilling Project, Leg 11. In Hollister, C. D., Ewing, J. I. et al., 1972. Initial Reports or the Deep Sea Drilling Project, Volume XI. Washington (U.S. Government Printing Office). 1009.

Rye, R. O., 1966. The carbon, hydrogen, and oxygen isotopic composition of the hydrothermal fluids responsible for the lead-zinc deposits of Providencia, Zacatecas, Mexico. Econ. Geol. 61, 1399.

Saito, T., Ewing, M., and Burckle, L. H., 1966. Tertiary sediment from the mid-Atlantic Ridge. Science. 151, 1075 .

Shieh, Y. N. and Taylor, H. P., Jr., 1969. Oxygen and carbon isotope studies of contact metamorphism of carbonate rock. J. Petrol. 10, 307.

Sverdrup, H. U., Johnson, M. W., and Fleming, R. H., 1942. The Oceans. (Prentice Hall). 1087 p.

Thompson, G., Bowen, V. T., Melson, W. G., and Cifelli, R., 1968. Lithified carbonates from the deep sea of the equitonal Atlantic. J. Sedim. Petrol. 38, 1305.

Wenner, D., 1970. Hydrogen and oxygen isotopic studies of serpentinization of ultramatic rocks. Ph.D. thesis, Calif. Inst. of Technology.

Worsley, T. R., 1970. The nature of the terminal Cretaceous event as evidenced by calcareous nannoplankton extinctions in Alabama and other areas. Ph.D. Thesis, Univ. of Illinois. 